\title{
Systemic approach diagnosis to development and technological packages adoption for a sustainable sectoral agricultural
}

\section{Diagnóstico, desarrollo y adopción de paquetes tecnológicos para una agricultura sectorial sostenible desde un enfoque sistémico}

\author{
NIVÓN-PELLÓN, Alejandra†*, VALENCIA-PÉREZ, Luis Rodrigo, VIVANCO-VARGAS, Martín \\ and CASTAÑEDA-OLALDE, Arturo
}

Universidad Autónoma de Querétaro, Faculty of Accounting and Administration, Mexico.

ID $1^{\text {st }}$ Author: Alejandra, Nivón-Pellón / ORC ID: 0000-0002-1715-4335, Researcher ID Thomson: V-8717-2018, CVU CONACYT ID: 668097

ID $1^{\text {st }}$ Co-author: Luis Rodrigo, Valencia-Pérez / ORC ID: 0000-0002-1590-5000, CVU CONACYT ID: 294393

ID $2^{\text {nd }}$ Co-author: Martín, Vivanco-Vargas

ID $3^{\text {rd }}$ Co-author: Arturo, Castañeda-Olalde

DOI: $10.35429 /$ JNAS.2020.21.7.1.13

Received July 10, 2020; Accepted December 30, 2020

\begin{abstract}
Technology in the agricultural sector can be defined as the set of technical knowledge that can result from the study and / or individual or collective experience that, in conjunction with practice, develops human skills and abilities. Technological innovation is fundamental to reach and maintain the levels of competitiveness that market requires, such as quality, organic production and nutritional content. The detection of actors, their activities, resources and capacities of a product chain system is needed, in order to develop technological packages for a singular type of crop, local circumstances and characteristics of the producer. The growing development of the wine sector in the country is a fertile field for the adoption of technological packages that promote precision agriculture in a harmonic and sustainable development. Improving the conditions and quality of the grape for winemaking, increasing the wine's storage potential and its nutraceutical nature. The opportune diagnosis of opportunity areas in the vineyard will help a sustainable management of the crop applying natural treatment in the opportune moment and precise place.
\end{abstract}

Innovation systems, Technological packages, Winemaking, Precision agriculture

\begin{abstract}
Resumen
La tecnología en el sector agrícola puede definirse como el conjunto de conocimiento técnicos que pueden resultar del estudio y/o experiencia individual o colectiva que en conjunto con la práctica desarrolla habilidades y capacidades humanas. La innovación tecnológica es necesaria para lograr la competitividad en los productores agropecuarios que en la actualidad el mercado demanda: cultivos orgánicos o bien que hagan uso mesurado de pesticidas, de alta calidad en aspecto y contenido de nutrientes. La detección de los actores, sus actividades, recursos, capacidades en un sistema de producción es básica para el desarrollo de paquetes tecnológicos adaptados a cada tipo de cultivo, circunstancias locales y características del productor. El creciente desarrollo del sector vitivinícola en México es un campo fértil para la adopción de paquetes tecnológicos que fomenten la agricultura de precisión su desarrollo armónico y sostenible. Y a su vez mejoren las condiciones y calidad de la uva para vinificación acrecentando el potencial de guarda de los vinos y su carácter nutracéutico. El diagnostico de las áreas de oportunidad en el viñedo ayudará a la gestión sostenible del cultivo aplicando tratamientos naturales en el momento adecuado y preciso lugar.
\end{abstract}

Sistemas de innovación, Paquetes tecnológicos, Vitivinícola, Agricultura de precisión

Citation: NIVÓN-PELLÓN, Alejandra, VALENCIA-PÉREZ, Luis Rodrigo, VIVANCO-VARGAS, Martín and CASTAÑEDA-OLALDE, Arturo. Systemic approach diagnosis to development and technological packages adoption for a sustainable sectoral agriculture. Journal of Natural and Agricultural Sciences. 2020. 7-21:1-13.

\footnotetext{
* Author Correspondence (Email: alejandra.nivón@ uaq.mx)

$\uparrow$ Researcher contributing as first author.
} 


\section{Introduction}

The concept of innovation according to Dossi (1988), is related to discovery, experimentation, development, imitation and adoption of new products, new technologies, new production processes and new organizational forms. Therefore, technological innovations imply, among other things, the structuring and development of technological packages that encompass scientific and empirical knowledge necessary for the development and implementation of a service or the production of goods, this knowledge can be adaptations or novelties, free access or legally restricted.

According to the definition of Solleiro et al, (1993), technology is understood as the "set of organized knowledge that constitutes a productive force that drives growth, that modifies the characteristics of work and nature and creates new comparative advantages that promote competitiveness".

For the objectives set out in the present, according to Janvry and Martínez (1971), a differentiation will be made between scientific knowledge and technical knowledge, understanding the former as that which defines the general framework for the development of science that gestates inventive capacities and abilities and, in turn, Instead, it can be applied to technical knowledge, as well as to production and transformation methods or functions.

In this context, the techno-scientific conjunction allows the generation of technological packages appropriate to each producer and adapted to all circumstances, because it also considers the immediate past and recent trends, the characteristics of the organizations, the type of government, the role that companies play in investments, as well as local economic and social development, budgets, and consulting activities (Rojas and Armegual, 1997).

Today's society recognizes the importance of technology in modern life, indeed, in Western culture there is a tendency towards a technocratic idealism for solving problems that are not only restricted to productive aspects, but also to aspects of a social and social nature. political (Drengson, 2011).
The use of technology in the agricultural sector has historically been a tool that mediates between human labor and nature. According to Herrera (2006), its basic function is to contribute substantially to transforming nature for the benefit of the people who live in the countryside. In the West, it is a linear process that involves the replacement of traditional techniques by commonly technological innovations (Cáceres, 2015).

The technological impact on the agricultural sector is controversial, as it has increased production and performance in the global agricultural sector (Pingali, 2012), increasing productivity and facilitating labor, which makes the work itself less routine and more comfortable. However, the British agricultural revolution (18th century to mid-19th century) generates speculation by addressing issues of over-exploitation of soils and the implementation of cultivation techniques that affect the environment. On the other hand, the agricultural technological impact stands out for its productive potential and its capacity to produce food for an increasingly numerous population (Borlaug, 2000). However, there are negative effects when analyzing dimensions such as environmental and socioeconomic (Patel, 2012).

Currently, Mexico and Latin America share a series of problems in the agricultural field that have generated technological and productive lag in rural agricultural areas, economic, cultural and social limitations that cause persistence of poverty and promote migration of large numbers of people in looking for better living conditions which generates the abandonment of the field. The pertinent diagnosis of this problem is required in order to make viable technological proposals that rescue and provide technical advice to the work of the field in a feasible way and that in turn are perceived as opportune and desirable by the small agricultural producer (Alvarez, 2016; Glio, 1986). 
Therefore, it is considered an important and pertinent contribution to propose and discuss appropriate and timely analyzes to the different agricultural sectors of the producing areas in order to diagnose and promote technological change in a relevant way and develop technological packages that solve real needs of producers and that respond to consumer demands locally, this from a holistic point of view that "guides the articulation of theoretical roots for the analysis of complex systems and the empirical relevance of intervention methods" (Borrás and Edquist, 2019; Robert and Yoguel, 2020).

Technological management has been described as the cycle of activities related to the identification, obtaining, research, development and acquisition of new technologies for the development or innovation in technologies applied to product, process, service, administration and / or direction, in a company; likewise, it promotes and coordinates technological changes related to the environment (Escorsa and Vallas, 2005).

On the other hand, Coy (1999) points out that technological management is a discipline that combines engineering with management activities in business, such as: a) management of technological components in individual product life cycles, b) capitalization of technological advances to achieve a competitive advantage and c) relationship and integration of product and process technologies.

The technological management of the Mexican field, in addition to including the characteristics and actions described above, must diagnose needs, develop solutions and / or adapt them according to the particular resources of each producer, as well as prospect the benefit or deterioration that each of these actions will cause with the passing weather.

\section{Framework}

The term Sustainable Development was first introduced in the Brundtland report in 1987 by the United Nations World Commission for Environment and Development. From this moment on, it was disseminated as "the type of development that allows current activities to be satisfied without compromising the ability of future generations to satisfy theirs." The pillars for the construction of a sustainable environment are described as the social, economic and environmental environment (United Nations, 1987).

The United Nations General Assembly, as a result of prospective exercises and with the purpose of "directing the changes and innovations to come", adopts the 2030 Agenda for sustainable development in September 2015. In it, 169 objectives are proposed to be developed in the next 15 years. To achieve this, 193 countries pledged to put in place the means necessary for its implementation through partnerships focused especially on the needs of the poorest and most vulnerable. Each country has full sovereignty over its wealth, resources and economic activities to set its own national goals in line with the Sustainable Development Goals (SDG).

The foregoing requires a deep analysis of the productive systems in order to achieve the recognition of the actors, resources and emerging niches.

The challenges of innovation should not only focus on technological potentials for the sake of greater economic gain, but it is also necessary to take into account social and environmental changes, which have been widely studied, even from a systemic approach (Dosi, 1982; Freeman, 1992; Pérez, 2010; Geels, 2002; Smith, 2006, 2010; Schot, 2007, 2018).

Understanding a system as a whole and its interaction with other existing systems at a given moment in time is of utmost importance in order to understand the prevailing social and technological regimes. This will allow to efficiently prospect its possible changes and evolutions for the generation of public policies, organizational networks, institutional training and learning environments (Schot and Kanger, 2018; Smith 2006; Fuenfschilling, 2012). 
Smith (2006) proposes an interesting coevolution between social and technical elements of an agri-food system, technical elements for the management of the crop from the fundamental biological knowledge of respiration and post-harvest treatments, process and added value, logistics, commercialization and needs From the market; in addition to everything related to social needs and customs linked to the production chain: beliefs, land management, educational level, environmental needs, as well as the historical value it represents, its importance and cultural value. Together, all these elements give structure to sectoral production systems, which in turn are socially and technologically interdependent with other equally dynamic systems.

\section{Models of agri-food technological change}

Understanding the models of technological change that have induced the growth of agricultural sectors is important, since from this analysis the present can be understood to plan and develop well-foreseen technological improvements from, for example, the policy approach for transformative innovation (Leach et al, 2012) or from policies oriented to holistic innovation (Borras and Edquist, 2019).

Among the prevailing models of technological change, those proposed by Janvry and Martínez (1971) and Ruttan (1982), which take up the "Induced Innovation Theory", imply development networks between producers, research institutions, input producers and markets. ; in addition to assuming homogeneity in the size and type of farms. Ruttan's model views agricultural technology as a public good; and the economy, made up of different social groups that benefit to varying degrees from the presence of that good. However, these models have had little impact in developing countries, such as those of Latin America, since they have not been able to consolidate networks between the various agents of the agricultural system.

On the other hand, it is important to point to the British agricultural revolution as a precedent and example of technological change; since, he proposed a pattern of generation and technological diffusion with resources from the owners, and from there several models of agricultural growth emerged.
Among which stands out the "Urban Impact Model", which has allowed regional development in mainly European industrialized countries through products such as: beer, olive oil, cheeses and sausages (Patel, 2012). This model has limited applications in developing nations, since it does not have the articulation between the primary sector, which produces the raw material, and the secondary sector that processes and transforms it.

The wine sector worldwide, probably due to the age of the viticultural practice, in conjunction with the oenological sector, is one of the few articulated sectors, since it has the natural need for raw materials and the immediate process to achieve quality wines.

In Mexico, the companies dedicated to the production of wine are mostly linked to the production of grapes for winemaking in specific areas, defined by climatic conditions. The foregoing is in line with the Urban Industrial Impact Model that describes the efficiency and proper functioning of agricultural economies close to industrial transformation centers. What allows the reduction of transportation costs and promotes local economies; Furthermore, it contributes to the improvement of urban infrastructure and the growth of regional technological capabilities. The above can be clearly observed in the oenological corridor that is located in the State of Querétaro, Mexico; between the municipality of Tequisquiapan and the magical town of Bernal, which also crosses the urban area of Ezequiel Montes.

On the other hand, the study and analysis of the models of technological transfer to the agricultural sector is of utmost importance to promote the adequate adoption of technological packages, it is important to mention that in the fifties it was intended, especially in Latin America, to transform the peasant in an economic agent in such a way that the technologies generated by the research centers were transferred and made available to solve a large number of the problems of peasant farmers. However, the appropriate technologies were few, probably due to limitations and lack of training for end users, as they did not understand the technology itself. Consequently, the "Diffusion Model" of technical knowledge was not successful. 
This model was succeeded a decade later by the "Modern Input Model", which states that the development of the traditional agricultural sector can only be achieved with investments in experimental centers that produce and provide highly profitable technical inputs that are effective for a particular society. (Solleiro et al, 2015).

Paiva, Schattan and Freitus (1976) developed the "Model of Self-Control Mechanisms", in which the adoption of technology is the decision of each farmer and livestock producer, since it is who evaluates the change in productivity with respect to traditional methods and the economic advantages. Likewise, these authors point out that technological diffusion also depends on the availability of technical knowledge, material resources, bank loans and management skills on the part of farmers and livestock producers.

For their part, Piñeiru and Trigo (1983) make an analysis of the innovation process and argue that they are not conceived as a homogeneous whole, but rather that disparities and imperfections in market action are recognized. In the same way, they make an important interpretation that provides a holistic and dynamic approach in which endogenous and exogenous elements are incorporated into the agricultural sector from a set of dimensions linked to the producer sector with society and the State.

Although some of the aforementioned Models highlight the importance of research centers as an actor in agricultural systems. In this regard, in the analysis carried out by the 2007 International Seminar on "Improvements in Agricultural Innovation Systems", organized by the Department of Agriculture and Rural Development of the World Bank, it is recognized that: currently research systems can increase the offer of new knowledge and technologies but they do not necessarily have the capacity to promote the adoption of innovations in the agricultural sector, therefore, there is no correlation with the economic growth of the sector.

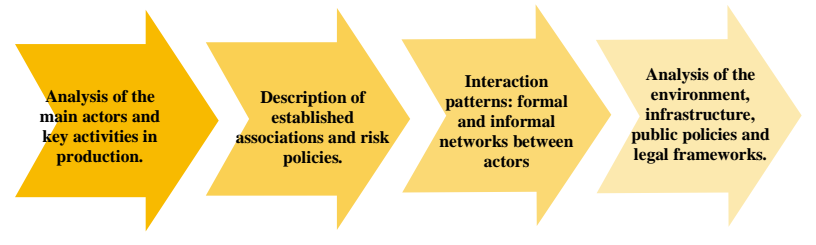

Figure 1 Stages for technological innovation in agricultural systems

Source: Own elaboration Adapted from the World Bank, 2008

A year later, in 2008, the World Bank establishes that the analysis of the elements that make up an agricultural technological innovation system must be carried out and proposes the stages illustrated in Figure 1.

This analysis can offer frameworks for studies that seek to develop technological packages appropriate to the local and specific context, which will benefit research centers and the knowledge economy. It is a tool in decisionmaking that could influence public policies, in support of technological change and innovation.

Currently it is understood, according to Alemán (2020) that the productive processes directly affect the natural resources of the region, its inhabitants, and the local economy, in addition to the linear and non-linear relationships between all the actors in the system. Therefore, the adequate intervention of innovation policies and the adoption of ad hoc technology represent an advantage for the management of a specific agricultural or livestock system, allowing its orientation towards more sustainable practices: respectful with the environment, focused on the development of the community at all levels and the growth of economic opportunities (Robert and Yoguel, 2020).

\section{Methodology}

In the present work, a field and literature analysis is carried out, from a phenomenological systemic approach, of the current characteristics of the wine sector in Mexico with attention to the Queretaro oenological corridor and the factors that intervene and make technological innovation feasible for cultivation. and production of the vine in a sustainable way, with the aim of visualizing and prospecting areas of opportunity to direct its management towards more sustainable practices. 
And thus, to encourage future studies that diagnose and structure theories about technical change in other agricultural sectors, in order to develop and adapt technological packages appropriate to each producer according to their environment, resources and needs.

Rojas and Armegual (1997) mention that when you want to establish a relationship between science and technology in developing countries, it is necessary to include basic topics such as: the immediate past, recent trends, the characteristics of organizations, policies public companies from previous decades, prominent companies, consulting activities among others. Therefore, this study describes the most relevant antecedents of the problems of the agricultural sector in Mexico and Latin America and some of the main characteristics of the country's wine sector; Likewise, some theories about technical change in agriculture are exposed (useful for studying the primary sector dedicated to the production of grapes for winemaking), as well as a sustainable technological proposal for the viticultural sector of the Querétaro region.

At the end, the strengths and opportunities in the technological innovation system in the grape and wine agroindustrial sector are analyzed, to raise the importance of the development and adoption of technological packages that allow the growth of the technological capabilities of the sector taking into account own resources regionally and locally.

\section{Analysis and discussion}

\section{History of vine cultivation in America}

The habit of wine consumption in Mexico has suffered ups and downs, since the introduction of the first vine vines for winemaking brought from the old world. During the colonial era, Hernán Cortés ordered every inhabitant of New Spain to plant 100 vines for each slave he had, which fostered the proliferation of vineyards in the central zone of present-day Mexico; This caused protests by wine producers in Spain, so that years later Felipe II ordered them to be uprooted and prohibited their cultivation in the new world.
In later times, presidents such as Porfirio Díaz and Francisco I. Madero favored and promoted vine production in Mexico and the development of the oenological industry for winemaking. The cessation of imports of European wines to Mexico after the First World War also promoted the development of the sector, so in 1948 the National Association of Winegrowers arose and by 1979 the vineyards occupied an area of 40,000 hectares in ten different wine-growing regions from the country; during that time the national production had an annual growth of 275\% (Álvarez, 1991).

The absence of international competition, due to trade protectionism, implemented during the import substitution model, continued until 1985, and worked against the technological development of viticulture; causing delay and wines of lower quality than their peers in other countries.

After the liberation of foreign trade with the signing of NAFTA, the wine industry in Mexico was at the mercy of the world market and international competition, which caused the closure of important wine-producing houses in Mexico during the 90's. and a continuous decline in production until 2002 (Salomón, 2004). In addition to the above, the existence of an unstable economy and continuous devaluations of the Mexican peso, led to the problems of the agricultural sector that is described below.

\section{Problems of the agricultural sector in Mexico and Latin America}

The policy of readjustment through the devaluation of the exchange rate, during the period 1981 to 1989, caused a reduction in GDP per inhabitant in Mexico by $9.3 \%$ (ECLAC, 1990); In addition to the decrease in trade flows and the increase in protectionist policies, the deterioration in the prices of raw materials reduced the foreign exchange obtained from exports; Thus, the growing interest in foreign debt limited the management of resources in a world environment of transformations generated by the development of new technologies. 
In this scenario, the profitability of the agricultural sector was reduced, due to the price policy, the decrease in investment, internal inflation and the reduction in the real perception per capita. The productive structure was reoriented to goods for the consumption of the higher-income population, with this profitability rose, but the concentration of capital, business infrastructure and technological resources was encouraged (Solleiro, 1993).

The problem of this restructuring policy aimed at modernizing economic sectors and specializing in specific areas to favor them competitively, brought not only economic consequences by promoting the production of goods that only reached privileged sectors of the population; but also technological due to the deficient development of capacities at the local level. The foregoing, due to the fragility of the scientific base and the poor adaptation of the technological options selected to make adequate use of local resources (ECLAC, 1989).

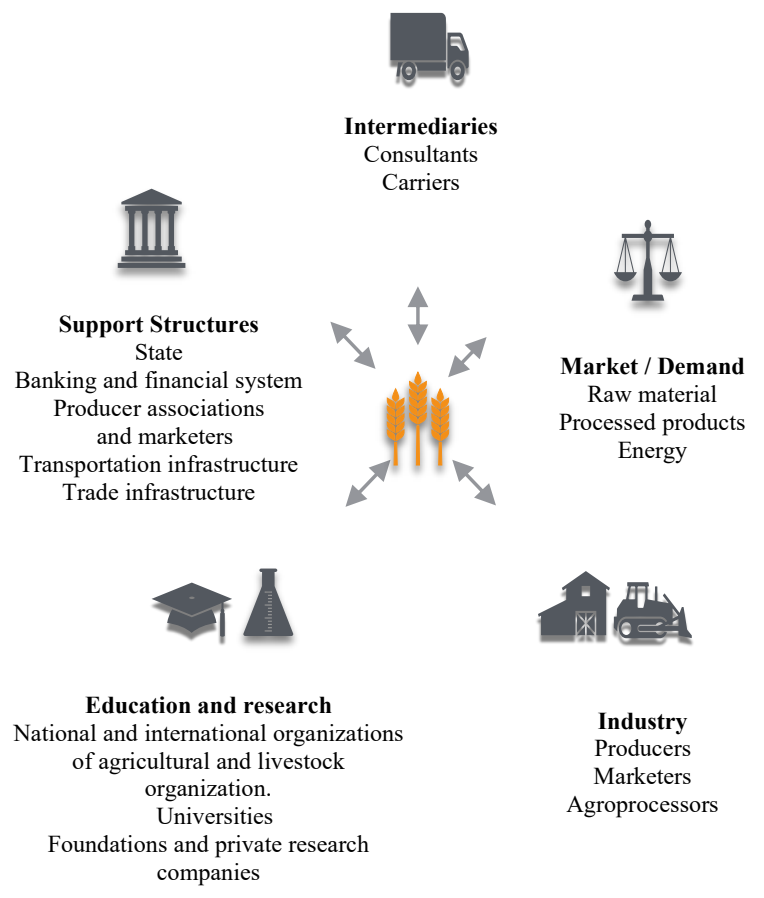

Figure 2 Main actors influencing agricultural and livestock technological change

Source: Own elaboration, adapted from OECD, 2005

When describing the agents involved in the behavior of the agroindustrial sector in Mexico, especially those that influence technological change (Figure 2), it is necessary to highlight the primary producers, the agroindustry, the producers of agricultural inputs and equipment, the social organizations, private and financial, to the State and research and development centers.
All of them have experienced devaluations, trade liberalization and adjustment policies individually, and have worked together. Therefore, clarified collaboration networks are now beginning to be seen (Kondo, 1992).

\section{Scenario for technological innovation in the wine sector in Mexico}

The Mexican wine that until 1984 enjoyed commercial protectionism faced the opening to the international market. What caused that between 1985 and 1994 the cultivation of the vine decreased from $70,520 \mathrm{Ha}$ to $41,000 \mathrm{Ha}$ and the number of wine companies registered in 2002 was only 16 (Álvarez, 1991). In this scenario, drinks such as beer, Tequila and Mezcal prospered by becoming a stable and demanding market.

Currently, wine consumption in Mexico is scarce compared to European countries where the average per capita consumption exceeds 40 liters per year (Meraz 2013). Even so, there is a sustained growth of the sector that could well be studied from the perspective of a luxury goods business more than from the food approach (Salomón, 2004), since it has been added to the national tourist and gastronomic offer, offering packages that include visits to the region, the wineries and vineyards, wine tasting and pairing, thus creating the wine tourism sector that offers its services to the upper middle economic market of the country.

For the year 2013, the economic contribution of the wine sector in Mexico was estimated to be around 137 million dollars annually with exports to more than 27 countries, which generated more than five million jobs in work in the vineyard, winery and sale of the produced broths (Meraz, 2013).

\footnotetext{
Currently, this Mexican industry is made up of more than 90 wineries and grape producers for winemaking, located in different winegrowing areas. Almost $90 \%$ of them in Baja California and the rest in Coahuila, Querétaro, Zacatecas, Guanajuato and Aguascalientes. Together they offer more than 350 wine labels. The hectares of wine grape plantations in the last five years have had an annual increase of $5 \%$, but the consumer market in Mexico is growing practically at double that rate. (Taken from: The Economist, June 2013)
} 
This scenario for the national wine sector allows us to assume that it is a fertile field for technological innovations due to its expansion to the tourism and gastronomic sector. In addition, the sale of luxury items such as "boutique wines" attract a national and international market with high purchasing power.

In 2013, the newspaper El Economista made an optimistic prospect: an increase in the consumption of wine in the country and the growth of the wine industry and its participation in the national market (between 30 to $50 \%$ by 2020). Forbes magazine for July 2018 reported: "With a lot of work, Mexican wine has a $29.3 \%$ share of the domestic market, compared to imported wines," with an annual production of two million liters.

For its part, the National Governors Conference has created a platform for the industry to flourish by increasing the vine growing area. With a plan approved in April 2018, part of the Law to Promote the Wine Industry has generated public policies to promote production capacities, infrastructure coupled with the management of wine tourism and gastronomic destinations (Mendoza, 2018).

\section{Sustainable proposals for the adoption of technological packages}

It is pertinent to project a model that serves as a frame of reference so that possible technological changes can be adapted to each of the agricultural models, from organic agriculture, family agriculture, intensive and extensive.

The term "technological fix" refers to technological implementations that seek to provide solutions to certain problems, but which in practice do not satisfactorily solve the problem raised and also create new problems (Scott, 2011, Cáceres, 2015). An example of this are the models that promote modern agriculture, since the "Green Revolution" (1960-1980), such as: the adoption of transgenic seeds, which after some cultivation cycles leave the soils worn out, and the use of pesticides that destroy regional ecosystems.
When analyzing the outstanding problems in the production of the primary sector, it is natural to be inclined to solve them by incorporating inputs or industrial equipment (Cáceres, 2015), there are still few actors in agricultural and livestock systems in Mexico that adopt practices that allow natural alternatives, such as: natural recovery of soils, use of fertilizers from bio-waste from the food processing sector, use of bumblebees or bees to promote genetic exchange via pollination, among others. Practices that constitute the foundation of technological packages oriented towards the sustainable management of production.

Currently, there are advances to face the problem in various sectors with non-invasive clean technology; The effective diagnosis of these areas of opportunity allows the development of suitable technological packages adapted to a specific agricultural sector, according to the region of cultivation, ecosystem, type of production and natural resources. This allows prospecting the effect that the suggested activities will have on various components of the agricultural, beekeeping, livestock or livestock system after a given period.

Lopera Palacios (1996) clarifies the foundation within a neoclassical vision for the growth of the agricultural and beekeeping sector that allows the sustainable integration of technology.

\footnotetext{
"The agricultural producer will tend to adopt those technologies that allow him to use as a priority the resources he has available and save those that are scarce. Resources that are relatively scarce for one producer may be relatively abundant for another, and vice versa. Therefore, the technological recommendations must be adapted to this diversity of circumstances [...]. To make an appropriate technological recommendation, it is not enough to know the technology, it is also essential to know the producer, his resources and his socioeconomic and cultural circumstances"
} 
Conducting specific research to give each producer a specific recommendation on particular circumstances until two decades ago was prohibitively expensive. At present, technology allows a diagnosis of the available resources in an efficient, relatively fast and low cost way, in order to offer the development of ad hoc technological packages to the particular needs from small producers to large companies in the primary sector. It is recommended that all technological packages observe the aspects established by the Ministry of Agriculture, Livestock, Rural Development, Fisheries and Food (SAGARPA, 2015), mentioned in the following Figure 3.

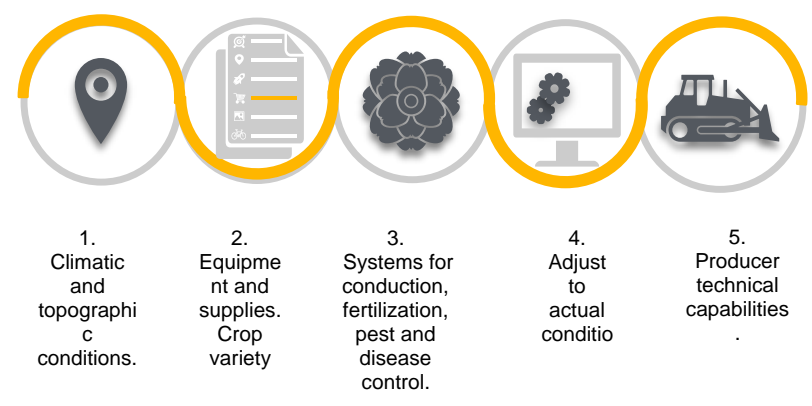

Figure 3 Factors to take into account for the development and acquisition of agricultural technology packages Source: Own elaboration Adapted from SAGARPA, 2015

Based on the above, the following section proposes technological resources that allow the diagnosis of the needs of the primary sector, particularly that of grape production for wine, of which its natural, technological and knowledge resources are considered, in order to that these are adequate to the needs of the producers and solve them satisfactorily.

Precision agriculture is a concept that encompasses diagnostic practices that aim to apply the correct amount of inputs, at the right time and in the exact place, through the use of technology, such as global positioning systems (GPS), multispectral cameras and unmanned aircraft (RPAS), to adapt soil and crop management to the variability present within a batch; which allows optimal management of large areas. The analysis of the results obtained in the diagnosis can be done on a sectoral or joint basis, which contributes to decision-making and the adjustment of differential cultivation management in the same field (Hernández, 2007, SISTAT, 2017).
Unmanned devices began to be used in Japan in the eighties, to increase the yield of crops. Since then, the Yamaha company, a leader in said technological development, has been improving its products, which are now also capable of spreading fertilizers and pesticides (Agroculturers, 2017).

A single unmanned aircraft or drone can monitor hundreds of square meters of land accurately, evaluating and collecting information on crop control, nutritional stress detection, hydration, irrigation, temperature, rate of crop growth, premature location diseases and other data, through photography and video in real time. In addition, many of the drones can be programmed to take off and land autonomously at predetermined times, and thus scare away birds and other animals that can harm the harvest. Most of these ships currently have integrated GPS technology, so they are able to fly over and perform their functions by themselves; There are even models that have two integrated cameras, additional to the one used for photographs or videos, through which they detect objects and thus prevent them from colliding with any obstacle (Hernández, 2007).

This allows those who manage the crops to have at their disposal a tool to control and increase productivity.

At present, the deployment of molecules dispersed in the leaves of vines or vines is a manual practice, which could well be carried out by an unmanned aircraft to which a tank has been adapted and flies over the crop lines at moderate speed, applying the liquid contained in the pressurized tank, through a graduated nozzle. This will allow the application of preventive doses of cupic sulfate commonly used in viticulture as an antifungal, the application of elicitore, biofertilizer or selected molecules in desired concentrations in order to promote certain metabolic pathways to help the production of phenolic compounds in varieties. grapevine, which can increase the aging potential and nutraceutical character of wines (especially red wines), as well as promote metabolic pathways for the synthesis of peptides and phytoalexins with antimicrobial activity (Martínez, 2008, Rivereau Gayon, 2001, Zarameño et al., 2015). 
On the other hand, it has been widely verified that the elaboration and application of biofertilizers made from waste from the food processing industry and / or seaweed, applied at the correct moment of the annual cycle of the vine, can increase fruit production. without this representing wear and tear on the vine. The foregoing aims to reduce the use of agrochemicals and pesticides or avoid them completely, not only in the wine sector (Zarameño et al., 2015).

Nowadays, there is an incentive for professionals to specialize in field diagnosis through the taking of images and their analysis allows young students to be interested in agricultural production, which has managed to reduce production costs and make assertive decisions regarding crops, in order to offer the world products of increasingly better quality (Valeiro, 2004). Similarly, according to the newspaper Expansión, in 2018, the yield of olive groves and vineyards has improved, allowing the sectorial agribusiness to strengthen and be more competitive.

The literary review and the visit to WEB sites of technology-based agroindustrial consultancies allow a compilation of the usefulness of RPAS in agricultural systems. It is observed that agribusiness 4.0 in Mexico and Latin American countries is possible, with the help of private and government capital in conjunction with higher education and research institutions (Nivón, Flores and Talavera, 2018).

Which, in addition to attracting qualified personnel interested in agricultural production, enables improvement and / or new processes for sustainable, environmentally-friendly productions and allows adequate and timely management of crops, as well as the application of substances only in areas of interest (Berrio et al, 2015; Stanley, 2014; Kho and Which, 2012).

One of the most promising sectors in this regard is the Mexican wine sector in order to improve production costs with a genuine interest in the production of wines of increasingly better quality that are planned from the field and improve cultural practices such as: antifungal treatments and application of biofertilizer (Arnó et al., 2009).

\section{Results and conclusions}

Baja California, Coahuila, Zacatecas, Guanajuato, Aguascalientes and Querétaro, are important states in the sowing and production of wine in Mexico. The field study allows us to describe the actors in the state of Querétaro, as follows: field and warehouse workers, distribution and promotion companies, regulatory bodies, enthusiastic consumers, expert and informed consumers, consumers who participate in events and promotions of enogastronomic tourism, international investment companies and professional investors with high purchasing power who have the possibility and enthusiasm to undertake vine planting with their own resources and manage crop management with the support of national and international consultancies. There are a few companies with foreign capital such as the Catalan company that produces sparkling wines, which has been a benchmark in Queretaro wine tourism.

The state of Querétaro (to the North $21^{\circ}$ 40 ', to the South $20^{\circ} 01^{\prime}$ of North latitude; to the East $99^{\circ} 03$ ', to the West $100^{\circ} 36^{\prime}$ of West longitude) is home to wine-growing houses in the municipalities: El Marques, Esequiel Montes, Pedro Escobedo, Colón, San Juan de Río and Tequisquiapan. With a little more than 500 hectares for the planting of vines (Contreras and Ortiz, 2019). Different types of soil are distinguished in the visited vineyards (black earth with high content of organic matter and chestnut with little organic matter, mostly tepetate), semi-dry climate with rainfall in summer, so cultural practices with systems of irrigation. Temperatures that reach $30^{\circ} \mathrm{C}$ in hot months and a minimum of $4^{\circ} \mathrm{C}$ in cold weather are recorded in some vineyards. It has been found that the plant tends to water stress in the months of April, May and June; with excess hours of sunshine during the year and lack of cold hours in the months of rest or lethargy of the vine.

According to Ramos, for the year 2019, the economic spill left by the Queretaro wine corridor in conjunction with its tourism and gastronomy activities was three billion pesos per year. At this time 27 companies belonging to the Querétaro Wine Growers Association (AVQ) have created a quality seal that supports 160 wine labels. 
Every year the Art, Cheese and Wine route receives more than ninety thousand visitors, which is favorably perceived by municipal and state authorities who support and participate in oenological events.

In contrast to most vineyards in Baja California, where the large valleys are divided between medium and small wine-producing companies that have a few hectares of cultivation, and independent vine producers whose work is sometimes not well paid, The viticulturists of the central area of the country are distinguished since their projects mostly begin with their own investment and some government support, always with the objective of growing the grapes that they are going to process in situ. For this reason, it is observed that their knowledge or search for advice ranges from sowing, cultivation, choice of varieties, climatic adaptation, and transformation process: must extraction, fermentation, filtration and aging.

This allows these emerging winegrowers to have a clearer area of opportunity for the development or adaptation of technological packages for the cultivation of the vine. Since they have the economic and technological capabilities that allow the training of winegrowers and day laborers; the purchase of equipment and the correct advice to collect information and analyze it in order to help the management of sustainable crops.

On the other hand, it has been possible to observe in the field work, the governmental interest that exists in the development of the Queretaro vineyard, for which the possibility of developing knowledge networks among winegrowers has been raised, such as: web platforms that allow the exchange of information and mutual help, with the support of universities and public and private research centers that diagnose and understand the points of improvement for each producer and the constant technological proposal by suppliers for the viticulture and oenological sector, which could generate a fertile field for the development of innovative proposals, adapted to the real needs of the sector.
The implementation of a pilot program that adapts a package tailored to the wine sector in this area, can allow evaluating in a real environment the use of remote sensing technologies for data collection, and their interpretation; which will allow winegrowers and winemakers to make assertive decisions at the right time for the right place.

In conclusion, once the history, development, main actors, types of investment, economic and technological capacities of the region have been analyzed, the introduction of remote sensing technology through remote sensing is perceived as important and pertinent for the actors involved in the emerging Queretaro wine sector. RPAS, in addition to being considered feasible and desirable by the guild. On the other hand, it is observed that they have technical preparation to evaluate the potential benefit that the interpretation of the images and the data collected can bring to their crops. The set of these factors makes a fertile field for the adoption of this technology according to: Berrio et al, 2015; Stanley, 2014; Kho and Which, 2012 among others.

Finally, RPAS is a rapidly advancing technology, so it is expected that in the short term more specialized drones for agriculture will be developed, so that in a few years they may be essential.

\section{References}

Aeroespacio, 2017. Actualidad aeronáutica y espacial. Japón estudia nueva regulación para drones. recuperado de http://www.aeroespacio.com.ar/index.php/indus tria-y-tecnologia/602-jap\%C3\%B3n-estudianueva-regulaci\%C3\%B3n-para-drones.html en marzo 2017.

Alemán Taco, F. X. (2020). La agricultura sustentable como alternativa para la gestión de empresas florícolas: caso Hilsea Investments Limited (Master's thesis, Quito, EC: Universidad Andina Simón Bolívar, Sede Ecuador).

Álvarez Asperó, 1991. La viña, la vid y el vino, Editorial Trillas, México. 
Agriculturers 2017. Drones para agricultura, beneficios y casos reales. Recuperado de http://agriculturers.com/drones-para-

agricultura-beneficios-y-casos-reales/ en marzo 2107.

Borlaug, N.E. (2000). Ending world hunger. The promise of biotechnology and the threat of antiscience zealotry. Plant Physiology, vol. 124(2),487-490.

Banco Mundial, 2008, Agricultural innovation systems: from diagnostics toward operational practices. Recuperado de: http://siteresources.worldbank.org/EXTARD/R esources/ARDDiscussionPaper38. pdf consultado marzo 2107.

Cáceres, D. 2015. Tecnología agropecuaria y agronegocios. La lógica subyacente del modelo tecnológico dominante. Mundo Agrario, 16. Recuperado de http://www.mundoagrario.unlp.edu.ar/article/vi ew/MAv16n31a08 en marzo 2107

Contreras, D. Y Ortiz, H. 2019. Turismo enológico y rutas del vino en México. Estado del conocimiento y análisis de casos. Revista RIVAR vol.6 no.17 Santiago mayo 2019.

Versión on-line: https://scielo.conicyt.cl/scielo.php?script=sci_ar ttext\&pid=S0719-

$49942019000200027 \& \operatorname{lng}=\mathrm{es} \& n r m=$ iso

Cory, J. (1999). Una Arquitectura de los Negocios para la Gestión Tecnológica. "Manual de Gestión en Tecnología. Una estrategia para la competitividad de las Empresas". Editorial McGraw-Hill. Colombia.

Dubourdieu y Ribéreau -Gayon, 2008. Traité d'oenologie - Tome 2 - 6e éd. - Chimie du vin. Stabilisation et traitements. ISBN: 97895050457.

Escorsa, Pere y Valls, Jaume (2005).Tecnología e Innovación en la empresa. $2^{\text {a }}$ Edición.Editorial Alfaomega. México

El Economista, 3 de junio 2013. El vino en México recuperado de http://eleconomista.com.mx/entretenimiento/20 13/06/03/vino-mexico. el 20 de marzo del 2017
Herrera, 2006 Innovaciones tecnológicas en la agricultura empresarial mexicana. Una aproximación teórica. Revista Gaceta Laboral Vol. 12, No. 1 Universidad Autónoma del Estado de México.

Hernández, 2007 Procesamiento Digital de Imágenes. Apuntes de Clases Ing. Forestal, Dr. Ingeniero de Montes Facultad de Ciencias Forestales y de la Conservación de la Naturaleza UNIVERSIDAD DE CHILE Actualización del capítulo "Percepción Remota" publicado en el libro "Manejo y Conservación de Recursos Forestales" Ed. Hernández. De la Maza y Estades.

Janvry y Martínez, 1971. Inducción de Innovaciones y desarrollo agropecuario Argentino recuperado de http://www.aaep.org.ar/anales/works/works197 1/Janvry_Martinez.pdf marzo de 2017.

Kondo L,"TLC y el nuevo Artículo 27 virtuales desafíos a la eficiencia productiva: JKL", entrevista en Agronegocios, junio de 1992, México

Lara, (1998). "Actores y procesos en la innovación tecnológica". Tecnología. Conceptos, problemas y perspectivas. Siglo Veintiuno Editores. UNAM. México.

Leach et al. (2012). Transforming innovation for Sustainability. Ecology and Society no. 17 pp 11-17.

Lopera, 1996. Capacitación para el desarrollo cafetero, fundamentos de economía agrícola. Lecturas complementarias sobre economía campesina y desarrollo tecnológico. Chinchina Federación de Cafeteros.

Meraz 2013. The historical importance of the wine making zone of Baja California. Multidisciplina Núm. 16, sep-dic. 2013.

Mendoza V. 2018. La lucha por fomentar consumo de vino nacional. Revista Forbes Julio de 2018. Recuperado de https://www.forbes.com.mx/la-lucha-porfomentar-consumo-de-vino-nacional/.

Patel, 2012. The long green revolution. Journal of Peasant Studies, vol. 40. 
Piñeiro y Trigo, 1983. Cambio técnico en el agro latinoamericano. Situación y perspectivas en la década de 1980

Pingali, P.L. (2012). Green Revolution: impacts, limits, and the path ahead. Proceedings of the National Academy of Sciences of the United States of America, vol. 109.

Paiva, Schattan y Freitus, 1976 Sector agrícola do Brasil; comportamiento económico, problemas y posibilidades, Editorial Universidad de Sao Paulo.

SAGARPA, 2015 Paquetes tecnológicos para el cultivo de caña de azúcar. Nota Técnica Informativa

SISTAT, Fotografía multiespectral UAV para agricultura PBX Virtual de Costa Rica recuperado de http://www.sisant.com/SISANTagricultura.pdf abril 20017

Scott, 2011. The technological fix criticisms and the agricultural biotechnology debate. Journal of Agricultural y Environmental Ethics, vol. 24.

Sollero, Del Valle, Sánchez La innovación tecnológica en la agricultura mexicana. Modernización de la empresa agropecuaria. Revista del banco de México.

Solleiro,J.L.; Aguilar Ávila, J.; Sánchez, Luz G., 2015. Configuración del Sistema de Innovación del Sector Agroalimentario Mexicano. Revista Mexicana de Agronegocios, Vol. 36, 2015.

Ramos, M. 2019. Querétaro apuesta por una ruta de queso y vino. Periódico Expansión 31 de octubre 2019.

Robert, V., y Yoguel, G. (2020). Exploración de nuevos conceptos en política de innovación. Secretaría de Investigación, Instituto de Altos Estudios Sociales. ISNN: 1851-8788

Rojas y Amergual. 1997. Ciencia y Tecnología en Venezuela. Comisión Presidencial para la reforma del Estado Editorial Arte. Caracas. Venezuela.

Ruttan, 1982. La teoría de la innovación inducida del cambio técnico en el agro de los países desarrollados. Universidad de Minesota EUA. 